\title{
Is There a Relationship Between Imprisonment and Crime in Western Europe?
}

\author{
Marcelo F. Aebi ${ }^{1} \cdot$ Antonia Linde $^{1,2} \cdot$ Natalia Delgrande $^{1}$ \\ Published online: 10 May 2015 \\ (C) Springer Science+Business Media Dordrecht 2015
}

\begin{abstract}
This article examines the evolution of prison populations in Western Europe from 1982 to 2011 and its relation with recorded crime trends in the region. Data are taken mainly from the Council of Europe Annual Penal Statistics in the case of prison statistics and the European Sourcebook of Crime and Criminal Justice Statistics in the case of police and conviction statistics, both complemented with the Nordic Criminal Statistics and Eurostat Crime Statistics. The results show that prison populations rates (stock) rose constantly until 2005 and seem relatively stable since then. On the contrary, the annual flow of entries into penal institutions has decreased almost continuously since 1987. This apparent paradox is explained by the fact that the average length of detention has steadily increased during the whole period under study. In brief, less people are sent to prison each year, but they remain in prison for longer periods of time. The upward trend in the average length of detention is related to the development of tough on crime policies across Western Europe and to the increase of drug offences and non-lethal violent crime until the mid-2000s. In that context, an analysis by offence shows similar trends in police, conviction, and prison statistics. These results falsify the hypothesis of total independence between crime trends and imprisonment rates. They also suggest that the deterrent effect of imprisonment has often been overestimated, and they cast a shadow on the validity of criminological theories that place property as the main cause of crime.
\end{abstract}

Keywords Average length of detention · Crime trends · Imprisonment rates · Flow · Stock · Violent offences · Western Europe

Marcelo F. Aebi

marcelo.aebi@unil.ch

1 University of Lausanne, School of Criminal Sciences, ESC - Sorge - BCH, Lausanne CH-1015, Switzerland

2 Universitat Oberta de Catalunya (Open University of Catalonia), Barcelona, Spain 


\section{Introduction}

From a theoretical point of view, prison population rates are sometimes seen as the consequence of crime rates, and sometimes as their cause. When prison population rates are seen as the consequence of crime rates, the logical reasoning is that countries with high crime rates will have higher prison population rates than countries with low crime rates. When prison population rates are seen as the cause of crime rates, the typical reasoning is that an increase in prison population rates could reduce crime rates. The reasons for that decrease would be (a) that the offenders neutralized can no longer commit offences (incapacitation); (b) that potential offenders can be discouraged from engaging in crime (general deterrence) but also, in the opposite sense, (c) that the release of an important number of prisoners - like the one that took place in Italy in 2006, when an amnesty reduced by one-third the prison population - can lead to an increase of crime. Indeed, a more rigorous methodological approach suggests that the linear model of cause and effect is not appropriate to describe this relationship. Circular causality (see, for example, Morin, 1977/1992) offers a better framework as, from a longitudinal perspective, crime comes first and is followed by punishment, which in turn could affect future crime, and so on.

From an empirical point of view, the relationship between crime rates and prison population rates is still a matter of discussion. Modern criminal justice systems are based on the principles of specific and general deterrence, trusting that the fear of incarceration will discourage offenders or potential offenders from committing offences. Policy makers often invoke incarceration as a panacea when hardening criminal laws. Criminologists, on the opposite, are extremely cautious when discussing the association between imprisonment and crime. The purpose of this article is to test whether there is a relationship between prison population rates and crime trends in contemporary Western Europe. Subsidiary, if such relationship exists, we will briefly discuss whether it has a causal nature and which is the causal order observed.

In the first section of the article we conduct a brief review of the literature on the relationship between prison population rates and crime rates. Then we include a methodological chapter that presents the data that will be used in the study. After that, we analyze the evolution of the stock of inmates and the flow of entries into penal institutions from 1982 to 2011 in Western Europe. In order to explain these trends, the following sections take into consideration the average length of detention during that period, the distribution of the sentenced prisoners by type of offence, and the evolution of crime according to police and conviction statistics. Finally, we discuss our main findings and their implications for criminological research and theory.

\section{Prior Research}

The relationship between prison population rates and crime rates can be studied both from a crosssectional and from a longitudinal perspective. A cross-sectional approach implies comparisons between these two rates in different countries, while a longitudinal approach concentrates on trends in these rates in one or in several countries. ${ }^{1}$ The following overview of the contemporary literature starts with studies that apply a longitudinal methodology and continues with those that use a cross-sectional one, although there are some studies that combine both perspectives.

\footnotetext{
${ }^{1}$ While in this article the units of analysis are countries, it is also possible to conduct similar studies using states or cities as units.
} 
Among the longitudinal studies, those analyzing the case of the United States are the most quoted in the recent criminological literature. The reason is that the increase in imprisonment has been used as one of the explanations of the crime drop observed in that country since the early 1990s. According to the economist Steven Levitt, the increase in incarceration in the United States during the 1990s accounted for a reduction of crime of approximately $12 \%$ for homicide and violent crime, "and $8 \%$ of property crime, or about one-third of the observed decline in crime" (Levitt 2004: 179). However, incarceration rates started increasing in the United States since the early 1970s and violent crime followed an upward trend since the early 1960s to the early 1990s (Tonry 1999). This parallel increase of incarceration rates and violent crime in the 1970s and the 1980s clearly contradicts the conclusions of Levitt (2004). The latter is aware of that contradiction and, in a footnote, he considers that "it is perhaps surprising that the rising prison population of the 1980 s did not induce a commensurate decline in crime in that period", and that "[a]mong adults, crime rates were in fact steadily falling throughout the 1980s", but that these declines "were masked by sharply rising youth crime in the 1980s", which appear to be due in part to the crack epidemic [...], as well as to falling punishments in the juvenile justice system over this same time period (Levitt 1998)" (Levitt 2004: 179). However, in his 1998 article, Levitt had stated that "[t]he rate at which juveniles were arrested for violent crime rose $79 \%$ between 1978 and 1993, almost three times the increase over that time period for adults" (Levitt 1998: 1156), and the only decrease that he mentions refers to the murder arrest for adults, which had fallen by $7 \%$. Reviewing the literature on this topic which includes mainly the works of Levitt (2004), Spelman (2000), and Donohue and Siegelman (1998) - Zimring (2007: 52) arrives at the conclusion that "incarceration played a rather modest role in the crime decline". The reason for the confusion about that role is the use of the term "elasticity" - taken from the economic literature and related to the relative effect of price changes and the quality of goods demanded - in a discussion of incapacitation effects, because "there is no mechanism remotely analogous to supply or demand in the mechanics of incapacitation" (Zimring 2007: 53).

In Europe, the relationship between prison population rates and crime rates has been studied through longitudinal analyses conducted mainly in Belgium, Italy, and France. Thus, analyzing the evolution of prison population rates in Belgium during almost 170 years (1831-1993), Vanneste (2001: 185) concludes that there is no relationship between the image of crime provided by police statistics and the one provided by prison statistics; but that, in terms of secular trends, the size of the prison population is best measured through the "strong signal" provided by the harsher sentences. For example, from 1843 to 1875 , for one life sentence imposed, the size of the prison population grew by 38 inmates, and for one sentence to forced labor (ranging from 5 to 20 years), it grew by 31 inmates (Vanneste 2001: 87). In the second half of the twentieth century, Vanneste (2001: 158) also found a strong long-term correlation $(r=.85)$ between the sentences to forced labor following a crime against persons and the prison population size. Melossi (2001) has analyzed long-term trends in Italy - from 1863 to the $1990 \mathrm{~s}$ - and found a correlation between the murder rate and the prison population rate, especially for the period 1947 to 1994 . He suggests as an explanation that the increase of murders —often related in Italy to those committed by the Mafia - creates a climate of generalized moral panic, fuelled by the mass-media, which leads the authorities of the criminal justice system to increase repression and therefore produces a rise of the prison population (Melossi 2001). Studying the situation in France from 1974 to 2005, Kensey (2007) considers that the increase in the length of the sentences imposed is responsible for the upward trend in the French prison population during that period. Her analysis of the distribution of the 
sentenced prison population is revealing: prisoners sentenced for simple theft represented $48.8 \%$ of the sentenced prison population in 1975 but only $7.5 \%$ in 2005 ; while, comparing the same years, those sentenced for assault increased from 6.1 to $17.6 \%$, and those sentenced for rape and sexual assault on minors and adults increased from 4.9 to $21.9 \%$. At the same time, homicide and qualified theft — which includes robbery - show stable percentages of roughly $9 \%$ each (Kensey 2007: 94). French police statistics also reflect an increase in rape, sexual assault, and assault from 1974 to 2004, while homicide increased from the 1970s to the mid-1980s, reached a peak in the early 1990s, and decreased until the end of the series in 2004 (Kensey 2007: 104-107).

Researchers that apply a cross-sectional methodology usually compare trends in crime rates and prison population rates in different countries, and they arrive to the conclusion that there is no relationship between them. For example, Newburn (2007: 15) points out that, with the noteworthy exception of homicide, "the main crime rates in the big cities in the United States and the United Kingdom are on a similar scale", but that "[even] though Britain is the highest incarcerator in Western Europe, its incarceration rate is only one-fifth (or less) of that in America". As a consequence, he arrives to the conclusion that "there is no direct link between crime rates and types and levels of punishment" (Newburn 2007: 15). The incredibly high incarceration rate of the United States compared to the ones of other Western democracies, led Tonry (1999) to apply, in a somehow ironic way, the concept of "American exceptionalism" which can be traced back to Alexis de Tocqueville. Tonry considers that a crudely empirical explanation, such as "American crime rates are higher or have increased more than other countries', and punishment patterns and policies are no more than a reflection of that reality [...] has virtually no validity" (Tonry 1999: 420-1). The reason is that the International Crime Victim Survey (ICVS) has shown that "[c]rime rates in the United States in the 1990s are, for the most part, no higher than in other countries" (Tonry 1999: 421). Referring to the work of Zimring and Hawkins (1997), Tonry concludes that "[w]here the United States stands out is in gun violence; our [U.S.] rates of robberies and assaults involving guns, and of gun homicides, are substantially higher than elsewhere" (Tonry 1999: 421).

At the same time, other international cross-sectional analyses have found that the European prison population rates were positively correlated with the rates of unsuspended custodial sanctions imposed for homicide and with the rates of homicide according to police statistics (Aebi and Kuhn 2000), as well as with the rates of homicide according to the World Health Organization mortality data (Lappi-Seppälä 2011). ${ }^{2}$ However, even when a correlation between homicide rates and imprisonment rates is found, researchers are extremely cautious as to the interpretation of their findings, which go against the mainstream position. ${ }^{3}$

The general impression that the reader gets after going through the scientific literature on the relationship between imprisonment and crime is that criminologists are extremely sceptical about it. The reader can also perceive a nuance between the position of criminologists working with data from the United States — who, overall, seem willing to accept a weak and indirect relationship — and criminologists working with European data who, in general, tend to deny

\footnotetext{
${ }^{2}$ Ouimet (2012) also found a positive correlation between incarceration rates and homicide rates for the year 2010 and using a sample of 160 countries.

${ }^{3}$ For example, Aebi and Kuhn (2000: 73) "have serious doubts about the veracity" of their findings; while, according to Lappi-Seppäla (2011: 308) "we cannot rule out the possibility that incarceration rates are partly influenced by differences in crime, especially in the East European and Baltic countries. This applies especially to homicide. [...] However, it is equally possible that high incarceration and homicide rates are both a product of a third factor. [...] This hypothesis deserves further examination in the future".
} 
any relationship in theoretical papers or, when confronted to empirical evidence of it, to treat it as an exception.

In practice, most contemporary researchers prefer relatively sophisticated models to explain imprisonment rates across nations, such as the ones developed by Cavadino and Dignan (2006a, b), Solivetti (2010), or Lappi-Seppälä (2011), which include several independent variables in the equation. The purpose of this article is much more modest as it concentrates only on the role of crime trends. In that context, the available research suggest that, in Europe, the hypothesis of a lack of relationship between crime rates and prison population rates seems valid only as far as cross-national comparisons of the levels of the total prison population and the total volume of crime are concerned. Indeed, in spite of the reluctance of most researchers, from a crosssectional point of view, European prison population rates seem partially influenced by crossnational differences in homicide (i.e., in general, countries with the highest homicide rates also present the highest prison population rates) and, from a longitudinal point of view, there is evidence from a few countries suggesting that trends in homicide and serious offences have been historically correlated with trends in prison population rates. Hence, the available literature seems to support the advise given by Garland (2013) in the sense that "when we compare rates of imprisonment across jurisdictions, or across time, any inferences we draw about repressiveness or punitiveness should be modified by consideration of the patterns, trends, and rates of crime to which these penal measures are a response" because "there is generally some relationship, however mediated and indirect" (Garland 2013: 487, emphasis in the original). ${ }^{4}$ This study tests whether the latter affirmation is corroborated in a group of Western European countries, adopting a longitudinal perspective that covers more than two decades and takes into consideration not only trends in homicide, but also in five other offences.

\section{Data and Methods}

The data on prisons and prisoners used in this article are taken mainly from the Council of Europe Annual Penal Statistics, which were started in 1983 and are better known by their acronym SPACE 5 (Aebi and Delgrande 2012). ${ }^{6}$ The exceptions concern data on prison populations and entries into penal institutions taken from the Nordic Criminal Statistics 1950-2010 (von Hofer et al. 2012) for Finland, Norway, and Sweden, and from the Direction of the Prison Services of the Ministry of Justice for France (Kensey 2007). Similarly, data on the distribution of sentenced prisoners in England and Wales are taken from the Home Office and Ministry of Justice series on Prisons and Probation Statistics and Offender Management Caseload Statistics. ${ }^{7}$

Data on persons convicted for criminal offences come from the five available editions of the European Sourcebook of Crime and Criminal Justice Statistics (CoE 1999; Killias et al. 2003; Aebi et al. 2006, 2010, 2014). The same is true for offences recorded by the police, with the exceptions of Finland, Norway, and Sweden —whose data come from the Nordic Criminal Statistics 1950-2010

\footnotetext{
${ }^{4}$ In a similar perspective, one of the main critics that Nelken $(2009,2010)$ addresses to the work of Cavadino and Dignan (2006b) is that they, "like most of those comparing a large range of incarceration rates, spend little time on persuading us that crime rates are really the same in all the countries they are comparing" (Nelken 2010: 61).

${ }^{5}$ The acronym SPACE derives from the French title of this series: Statistiques Pénales Annuelles du Conseil de l'Europe.

${ }^{6}$ The annual SPACE surveys since 2000 are available at www.unil.ch/space (last accessed on 14 December 2014). The previous surveys are available only in paper format.

${ }^{7}$ Available at www.gov.uk/government/organisations/ministry-of-justice/about/statistics. Last accessed on 14 December 2014.
} 
(von Hofer et al. 2012) - as well as Spain, whose data from 1994 to 2011 come from the database of Eurostat on crime and criminal justice. ${ }^{8}$ Police and conviction data are used with the adjustments described in previous articles that have used the same sources (see Aebi and Linde 2010, 2012a, b). Offences recorded by the police refer to the criminal offences subject to criminal proceedings registered by the police forces of a country. Correspondingly, persons convicted refer to persons found guilty, according to the law, of having committed an offence. This includes court convictions and sanctions imposed by the prosecutor — or by a court that ratifies a decision of the prosecutor without a formal court hearing - that lead to a formal verdict (for details and exceptions see Aebi et al. 2014).

The other indicators used in this research are the stock of inmates (available from 1983 to 2011), the flow of entries into penal institutions (available from 1982 to 2010), the average length of detention, and the distribution by offence of the prisoners serving a final sentence (available from 1994 to 2011). The stock of inmates (hereafter referred to as the stock) refers to the total number of prisoners, including pre-trial detainees, held in prison on a given date, which in the case of SPACE is the 1st September of each year. When calculated on the basis of 100,000 population, this indicator is indistinctly referred to as the imprisonment rate, the incarceration rate, the detention rate, and the prison population rate (Kuhn et al. 2000: 16). In this article, all these terms are used as synonyms. The flow of entries into penal institutions (hereafter referred to as the flow) corresponds to the total number of entries of persons in detention facilities - including those for pre-trial detainees - during a whole year. As Tournier (2004: 2) has shown, it is possible in this context to apply to the study of prison populations the demographic model of the stationary population. In this model, the stock $(\mathbf{S})$ is the product of the flow (F) multiplied by the length $(\mathbf{L})$, i.e., $\mathrm{S}=\mathrm{F} x \mathrm{~L}$. This formula can then be transposed to calculate an indicator of the average length of detention $(\mathbf{L})$ expressed in months by computing the quotient of the average number of prisoners in 1 year $(\mathbf{S})$ by the flow of entries during the same period (F), and multiplying the result by 12 in order to express it in months. ${ }^{9}$

$$
L=12 \times(S / F)
$$

This formula produces similar results when the stock refers to a given date of a year X and the flow to the previous year (X-1), and it is used in this article to calculate the average length of detention in the countries studied. In the case of stock, flow, sentenced prisoners by type of offence, police recorded offences and persons convicted for criminal offences, the rates per 100,000 population in each country are used to compute geometric means for the group of countries under study (Figs. 1, 2, 4 and 5). ${ }^{10}$ The average length of detention is also calculated

\footnotetext{
${ }^{8}$ Available at http://ec.europa.eu/eurostat/data/database. Last accessed on 14 December 2014.

${ }^{9}$ Imagine a country in which ten persons enter into prison every year, of which two persons are sentenced to 5 years, two to 4 years, two to 3 years, two to 2 years, and two to 6 months. If one places this figures on a spreadsheet, it can be seen that, from the 5 th year onward, the prison population of that country would be stable at 29 prisoners yearly. Thus, the stock of that hypothetical country is 29 and the flow 10 , while the average length of the sentences is 2.9 years $(5+5+4+4+3+3+2+2+0.5+0.5=29 \div 10=2.9)$. This means that knowing two of these numbers is it always possible to calculate the third one through the above formula. For example, with a stock of 29 and a flow of 10 , the average length can be calculated by dividing the stock by the flow $(29 \div 10)$ as 2.9 years or 34.8 months $(2.9 * 12)$.

10 "Geometric means are often more meaningful than arithmetic means, because they are closer to the central figure (median). [...] To calculate the [geometric] mean of n numbers, [...] multiply them, then take the $n^{\text {th }}$ root" (Taagepera 2008: 120). According to Dodge (1993: 248-9), the geometric mean is used in particular to calculate the average of ratios and reduces the influence of extreme values (outliers). Thus, it seems particularly appropriate for the data analyzed in this article, which include rates per 100,000 population and some outliers. In the field of crime trends, the geometric mean have been used namely by Eisner (2003) and Pinker (2011: 64).
} 


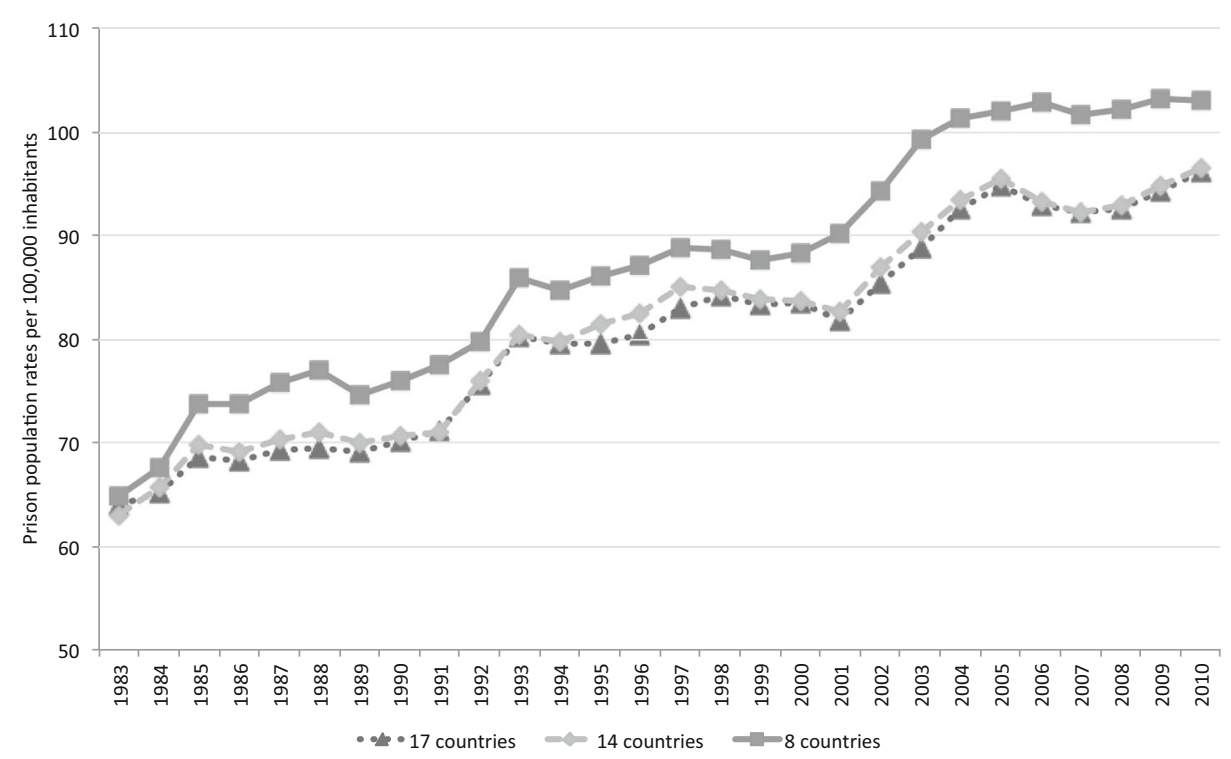

Fig. 1 Trends in the stock of inmates per 100,000 population in Western Europe from 1983 to 2011

as the geometric mean of the average lengths of detention of the countries included in the analysis (Fig. 3). Finally, the percentage change between the first and the last year of the series - based on a direct comparison of the rates for both years - and the average annual percent change, also known as average annual variation, annual growth rate, and average annual change rate (Harrendorf et al. 2010: 147) are used to measure the evolution of rates during the time frame of the analyses.

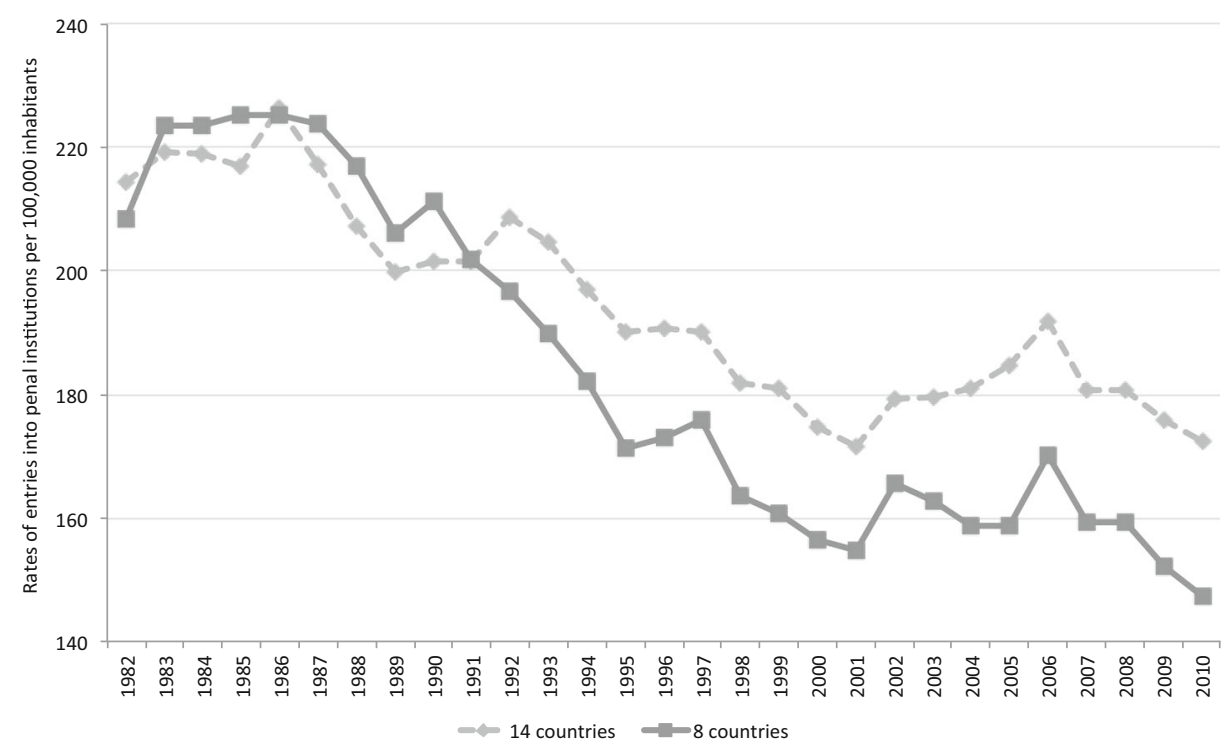

Fig. 2 Trends in the flow of entries into penal institutions per 100,000 population in Western Europe from 1982 to 2010 


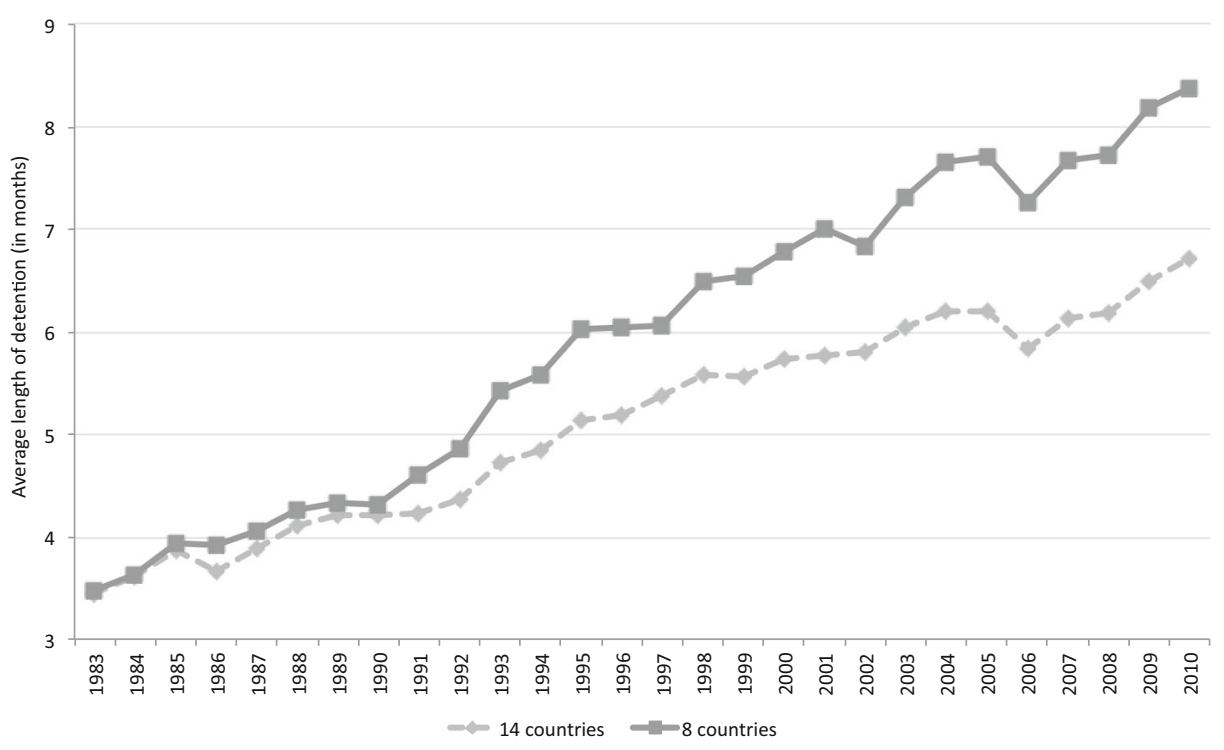

Fig. 3 Trends in the average length of detention in Western Europe from 1983 to 2010

Countries with a population of less than one million inhabitants are not included in our study because their presence can affect the reliability of the statistical analyses. For example, they may show substantial changes in their rates from 1 year to another that are only due to the addition or the subtraction of a few inmates, offences, or persons convicted. Germany cannot be included because, until the late 1990s, data are available only for the Federal Republic of Germany, usually known as Western Germany. Finally, as some countries had been unable to provide data for every year covered by our data sources, linear interpolation was used to calculate the missing values. When the first years of the series were not available, their values were extrapolated by repeating the value available for the first available year. When the last year of the series was not available, its value was extrapolated by repeating the previous available year. ${ }^{11}$ In spite of these adjustments, some countries cannot be included in all the analyses because they did not provide data on all the indicators required (e.g., in the case of Austria, data are available for the stock, but not for the flow). As a consequence, and in order to maximize the available data, three data sets are analyzed: (a) stock, (b) flow and average length, and (c) distribution of the sentenced prisoners by type of offence.

Stock data for the period 1983 to 2011 are available for the following 17 countries: Austria, Belgium, Denmark, England and Wales, Finland, France, Greece, Ireland, Italy, Netherlands, Northern Ireland, Norway, Portugal, Scotland, Spain, Sweden, and Switzerland. Flow data for the period 1982-2010 are available for 14 countries, because Austria, Greece, and Switzerland did not provide such type of data. As both stock and flow data are needed to calculate the average length of detention, the latter is available for the same 14 countries. ${ }^{12}$ Data on the

\footnotetext{
${ }^{11}$ Linear interpolation and extrapolation are the standard procedures for the replacement of missing data, which are used, for example, by the World Health Organization for the calculation of regional averages of homicide according to health statistics (WHO 2014).

${ }^{12}$ Belgium, Denmark, England and Wales, Finland, France, Ireland, Italy, Netherlands, Northern Ireland, Norway, Portugal, Scotland, Spain, and Sweden.
} 
distribution of sentenced prisoners by type of offence from 1994 to 2011 are available for eight countries because Belgium, Denmark, Ireland, Italy, Netherlands, and Northern Ireland did not provide reliable data. In order to improve comparability, the same eight countries are included in the analyses of offences recorded by the police. ${ }^{13}$ In the case of persons convicted for criminal offences, it was impossible to obtain reliable series for Norway and Spain, and therefore only six countries are included. Whenever possible, the three main datasets are included in the Figures. For example, Fig. 1 shows the trends in stock for the sample of 17 countries and the subsamples of 14 and eight countries. This kind of presentation of the results allows establishing whether the subsets show convergent or divergent trends.

\section{Findings}

This section presents the results of our analyses. It starts with a general overview of the trends in the stock and the flow of entries into penal institutions, which are then combined to establish the average length of detention. This is followed by an analysis of the distribution of sentenced prisoners by offence. Finally, we present crime trends according to police and conviction statistics.

\section{Trends in the Stock of Inmates}

Figure 1 shows the evolution of Western European prison population rates (number of inmates per 100,000 population) since 1983 . As mentioned before, in order to compare rates according to different indicators, the figure presents three clusters of countries. These clusters include the 17 countries that provided stock data since 1983, a subset of 14 of them that will be used for the comparisons with flow data, and a subset of eight of these countries that will be used for the comparisons with the distribution of the sentenced prisoners by offence as well as with offences recorded by the police.

Figure 1 shows an almost constant linear increase in prison populations, interrupted by short periods of relative stability during the second half of the 1980s, the second half of the 1990s, and, particularly, in the second half of the 2000 s, when prison populations started to stabilize and even decrease in some countries. For the clusters of 17 and 14 countries the annual average increase is $1.5 \%$ and for the cluster of eight countries it is $1.6 \%$. In particular, the 2011 rates were respectively, 51, 54, and $59 \%$ higher than the ones of 1983 . The analogy in the evolution of these rates for the three clusters of countries suggests that the inclusion or exclusion of a few countries does not affect the overall Western European trend. This similarity in the evolution of crime measures at the European level has also been observed in the case of police and conviction statistics (Aebi and Linde 2010, 2012a). Indeed, a country-by-country analysis (not presented here) shows that only Austria, Finland, and Northern Ireland show lower prison population rates in 2011 than in 1983. At the same time, the average annual variation of the stock from 1983 to 2011 is negative only in the cases of Finland and Northern Ireland.

\section{Trends in the Rates of Entries into Penal Institutions}

Figure 2 shows the evolution of the rate of entries (flow) into penal institutions per 100,000 population. Once more, in order to allow comparisons, the figure includes the

${ }_{13}$ This means that data on the distribution of the sentenced prisoners by offence as well as offences recorded by
the police are available for England and Wales, Finland, France, Norway, Portugal, Scotland, Spain, and Sweden. 
14 countries that provided flow data since 1982 and the eight countries for which information on the distribution of the sentenced prisoners by offence and police recorded offences are available.

The trends shown in Fig. 2 are almost the opposite to the ones of Fig. 1. With the exception of an increase in the first half of the 1980s and a period of relative stability in the first half of the 2000s, the flow of entries into penal institutions has been decreasing almost constantly for more than 20 years. All in all, in the cluster of 14 countries the 2010 rate is $20 \%$ lower than the one of 1982 and the average annual decrease is $0.9 \%$; while in the cluster of eight countries the rate is $29 \%$ lower in 2010 than in 1982 and the annual decrease is $1.6 \%$. Once more, both clusters show a similar evolution $(\mathrm{Rho}=.94 ; p \leq .001)$; even if the decrease is more pronounced in the smaller one. A country-by-country analysis shows that only Ireland, the Netherlands, and Northern Ireland show a higher flow in 2010 than in 1982, and that these countries and Scotland also show a positive annual average variation of their flow from 1982 to 2010.

A comparison of the trends in stock (Fig. 1) and flow (Fig. 2) for the years 1983 to 2010 shows negative and significant Spearman's rank correlations for the cluster of 14 countries $(\mathrm{Rho}=-.82 ; p \leq .001)$ as well as for the cluster of eight countries $(\mathrm{Rho}=-.90 ; p \leq .001)$.

\section{Trends in the Average Length of Detention}

Figure 3 shows the evolution of the average length of detention for the 14 countries that provided stock and flow data, and for the eight countries that provided data on the distribution of the sentenced prisoners by offence and police recorded offences.

The trend in Fig. 3 is similar to the one in Fig. 1 and consists in an almost constant linear increase in the average length of detention of all persons held in custody. The average annual increase is $2.4 \%$ for the cluster of 14 countries and $3.3 \%$ for the cluster of eight. Overall, for the cluster of 14 countries the average length of detention increased by $94 \%$ from 1983 to 2010, while for the cluster of eight countries it increased by $141 \%$. The Spearman's rank correlation between the evolution of both time series is $.99(p \leq .001)$. In particular, a country-by-country analysis shows that only Northern Ireland showed a longer average length of detention in 1983 than in 2010 as well as a negative annual average variation of such length during that period.

A comparison of the trends shown in Figs. 1, 2, and 3 for the period 1983 to 2010 reveals positive and significant Spearman's rank correlations between the stock and the average length of detention of $.97(p \leq .001)$ for the cluster of 14 countries and of .98 $(p \leq .001)$ for the cluster of eight countries. For the same period, it also shows negative and significant Spearman's rank correlations between the flow and the average length of detention of $-.89(p \leq .001)$ for the cluster of 14 countries and of $-.94(p \leq .001)$ for the cluster of eight countries.

\section{Distribution of the Sentenced Prisoners by Offence}

Figure 4 presents the trends in the distribution by offence of the sentenced prisoners in eight Western European countries, expressed as rates per 100,000 population, from 1994 to 2011. These rates correspond thus to the stock of prisoners by type of offence. For example, the rate of prisoners sentenced for homicide was 6.2 per 100,000 population in 1994 and it followed a curvilinear but overall upward trend until reaching 8.3 in 2011.

It can be seen that, from 1994 to 2011, the rates of prisoners sentenced for homicide, assault, rape, robbery, and drug offences have increased, while the rate of persons sentenced for theft has decreased. In particular, the upward trend in the rates of persons sentenced for 


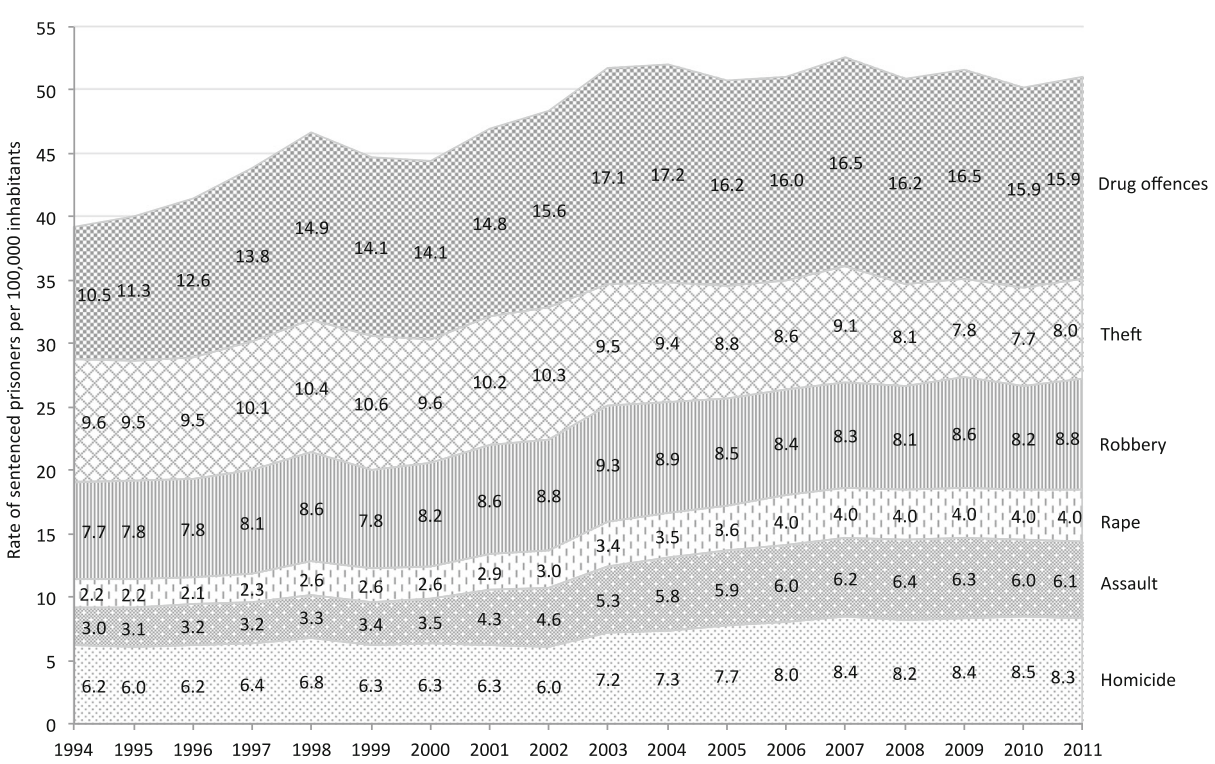

Fig. 4 Distribution of the sentenced prisoners by type of offence in eight Western European countries from 1994 to 2011 (rates per 100,000 population)

violent and drug offences tended to stabilize in the late 2000s. Comparing 2011 to 1994, the rate of persons sentenced for robbery increased by $15 \%$, for homicide by $35 \%$, for drug offences by $52 \%$, for rape by $78 \%$, and for assault by $101 \%$. On the opposite, the rate of persons sentenced for theft decreased by $17 \%$. The computation of the average annual percent change during the same period shows annual average increases of $0.5 \%$ for robbery, $2.1 \%$ for drug offences, $2.3 \%$ for homicide, $4.4 \%$ for rape, and $5.4 \%$ for assault; while theft shows an annual average decrease of $-1.5 \%$.

The country-by-country analysis of the average annual variation by offence presented in Table 1 corroborates these trends with a few exceptions. The rates of persons sentenced for homicide and assault increased constantly in each of the eight countries, the rates of persons sentenced for rape and drug offences increased annually in all countries with the exception of Portugal, while the rates of persons sentenced for robbery increased annually in all countries with the exception of Finland and Scotland. Finally, the rate of persons sentenced for theft decreased annually in all countries with the exception of Spain.

\section{Crime Trends}

Figure 5 shows crime trends according to police statistics for the same countries and the same offences presented in Fig. 4 and Table $1 .{ }^{14}$ The figure also includes crime trends according to

\footnotetext{
${ }^{14}$ It was impossible to include assault figures for England and Wales because of several major modifications in the legal definition and the statistical counting rules of that offence, which have increased artificially the number of assaults recorded by the police. Similarly, no reliable police data were available for theft and drug offences in Spain. Drug offences correspond to drug trafficking in England and Wales and to the total number of drug offences in the rest of the countries included in the analysis. Homicide corresponds to intentional homicide excluding attempts.
} 
Table 1 Average annual variation from 1994 to 2011 in the rate of sentenced prisoners per 100,000 population, by type of offence, in eight Western European countries

Finland France Norway Portugal Spain Sweden UK : England UK : Scotland
and Wales

\begin{tabular}{lrrrrrrrr}
\hline Homicide & 0.8 & 0.4 & 0.4 & 1.8 & 3.3 & 6.3 & 3.8 & 3.3 \\
Assault & 4.6 & 13.8 & 1.5 & 3.4 & 10.3 & 5.4 & 5.8 & 0.3 \\
Rape & 6.9 & 3.3 & 10.6 & -1.6 & 3.9 & 5.1 & 5.9 & 1.3 \\
Robbery & -2.9 & 2.5 & 3.2 & 0.5 & 0.7 & 2.4 & 2.9 & -5.0 \\
Theft & -4.1 & -4.4 & -3.8 & -4.2 & 10.7 & -5.9 & -0.5 & -0.2 \\
Drug offences & 1.7 & 0.9 & 2.2 & -2.7 & 2.3 & 4.5 & 5.0 & 1.2 \\
\hline
\end{tabular}

conviction statistics for six out of those eight countries because, as mentioned in the section on Data and methods, the full time series were not available for Norway and Spain. The left part of Fig. 5 presents the evolution of offences recorded by the police from 1990 to 2011, while the right part of it shows trends in persons convicted from 1990 to $2010 .^{15}$ In both cases, trends are presented on the basis of an index where $1990=100$.

It can be seen that the rate of police recorded offences for the six crimes included in this study increased at the beginning of the 1990s. Immediately after, homicide and theft started decreasing, while the rest of the offences continued increasing until the beginning of the $2000 \mathrm{~s}$ in the case of robbery - which have been decreasing since then - and the mid-2000s in the cases of assault and rape -which have been relatively stable at the end of the series. Only drug offences increased constantly during the whole period under study. Conviction statistics corroborate in general this evolution, although there are some differences especially during the last period of the series. Thus, the rate of persons convicted for homicide is rather stable since 1998 and those convicted for assault and rape not only stabilized in the mid 2000s but even show a slight decrease in the late 2000s, while in the case of robbery the downward trend was interrupted during that period. In general, the increases and decreases shown in conviction statistics are smaller than the ones shown in police statistics. ${ }^{16}$ These trends are consistent with the ones found by studies covering shorter time series but using larger samples of countries (Aebi and Linde 2010, 2012a, b, c; Gruszczyńska and Heiskanen 2012).

A country-by-country analysis (not presented here) shows that, in the case of police statistics, there are only a few exceptions to this general trend. In particular, Portugal shows a downward trend in the case of rape (the same is true for Spain) and drug offences (probably due to the decriminalization of drug use in 2001) and an upward trend in the case of theft. ${ }^{17}$ Trends in robbery must be interpreted cautiously. This offence is usually considered as an aggravated theft (i.e., theft with violence) in continental Europe, and it is not registered in the same way across countries. In particular, there seem to be huge differences as far as robberies of small electronic devices, such as mobile phones, are registered. As a consequence, robbery is currently the less appropriated offence for cross-national comparisons. Consequently, the trends in police and conviction statistics are not homogeneous. In particular, police recorded

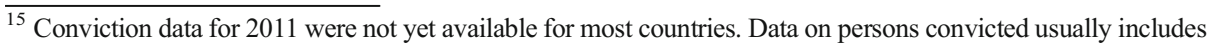
attempts.

${ }^{16}$ Only the rate of persons convicted for drug offences registered a higher increase than the rate of police recorded drug offences.

${ }^{17}$ As mentioned in the section on Data and methods, no reliable data on police recorded assaults were available for England and Wales.
} 


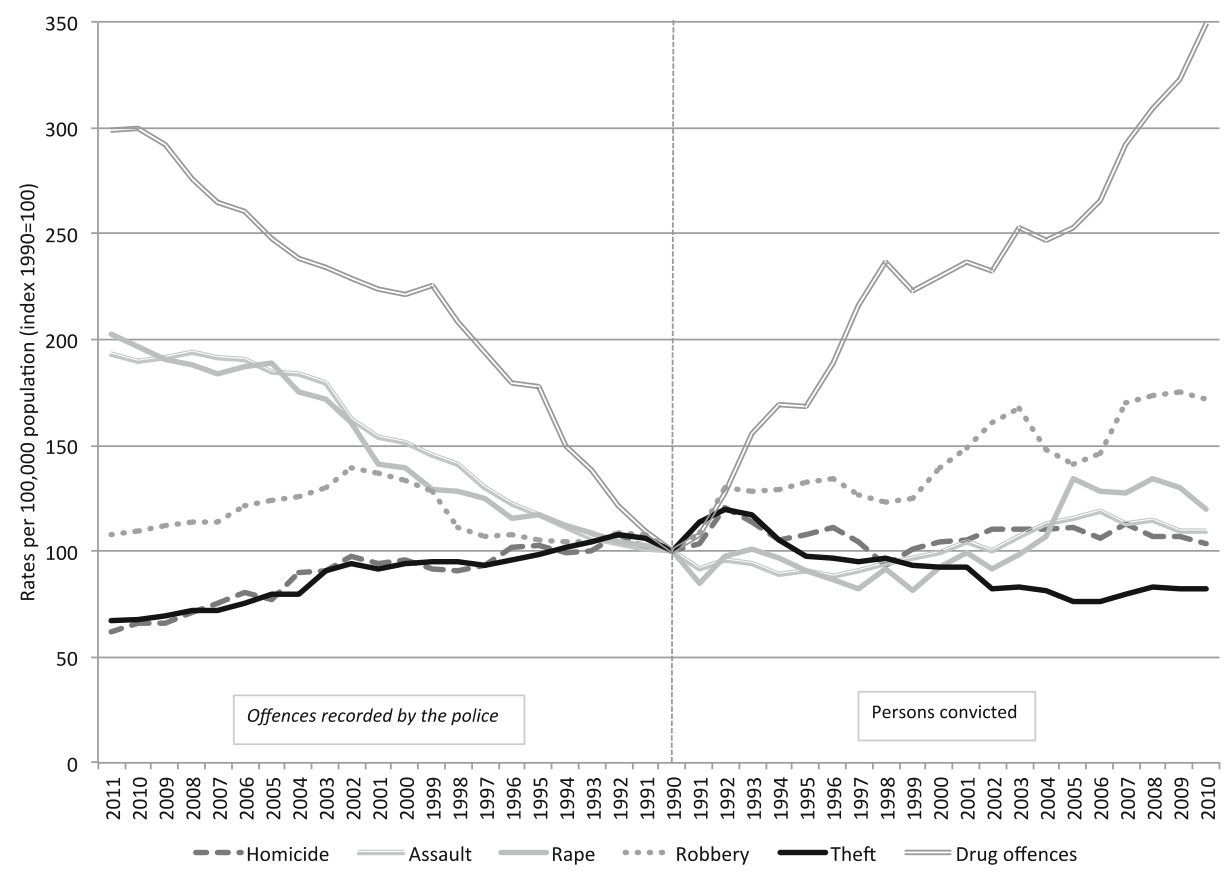

Fig. 5 Police recorded offences (left) and persons convicted (right) per 100,000 population in up to eight Western European countries, 1990-2010/11 (Geometric means, index 1990=100)

robberies decreased in England and Wales, Finland, Scotland, and Spain, while in France, Norway, Portugal, and Sweden they increased in the 1990s and remained relatively stable in the 2000s. At the same time, persons convicted for robbery increased in England and Wales, Portugal and Sweden, decreased in Scotland until the mid-2000s and remained stable after that, in the same way that they remained stable in Finland during the whole period. ${ }^{18}$ For the rest of the offences there are only a few exceptions to the general trends shown by conviction statistics in Fig. 5. In particular, the rates of persons convicted have remained stable in Finland for theft, they have decreased in England and Wales for assault, in Portugal for rape and in Scotland for robbery, and in France and Portugal for homicide. Regarding the latter, the trend is rather stable in the other four countries. This divergence between a stable trend in person convicted for homicide compared to a downward trend according to police data and World Health Organization mortality statistics (Aebi and Linde 2014) has also been observed with a larger sample of countries (Aebi and Linde 2012b). It seems related to an increase in the certainty of arrest and in the certainty of conviction for homicide (Aebi and Linde 2012b). The relative stability of the rate of persons convicted for homicide since the late 1990s (Fig. 5), accompanied by the increase observed in the average length of detention (Fig. 3), provide a plausible explanation to the growth of the rate of prisoners serving sentences for homicide since the early 2000s (Fig. 4).

In sum, at the very beginning of the 1990s, there was a general increase in police recorded crime and persons convicted for criminal offences. Then, drug related crime pursued its upward trend, while the increase in non-lethal violent crime lasted until the mid-2000s and

${ }^{18}$ Data on persons convicted for robbery in France were not available. 
was followed by a period of stability — and even slight decrease according to conviction statistics - until 2010/11. On the other hand, property crime and homicide decreased since the early 1990s to 2010/11, even if the rate of persons convicted for homicide remained rather stable in the 2000s. We will not discuss here the possible causes of these trends because the purpose of this article is not to explain crime trends but to analyze their relationship with prison population rates. $^{19}$

\section{Discussion}

\section{Increased Punitiveness and its Relationship with Crime Trends}

In Western Europe, prison population rates (stock) increased rather constantly from 1983 to 2005 and remained afterward relatively stable until 2011 (Fig. 1). At the same time, after an increase in the early 1980s, the annual entries into penal institutions (flow) decreased rather constantly from 1987 to 2011 (Fig. 2). These trends show a strong and significant negative correlation, which reflects the fact that, during roughly 15 years (mid-1980s and 1990s), they were completely opposite. This apparent contradiction between stock and flow trends is explained by the constant increase of the average length of detention during the period under study (Fig. 3). Indeed, the latter presents a strong and significant positive correlation with the stock.

The increase in the average length of detention has usually been considered as the consequence of increased punitiveness, which is related to the rise of populist punitiveness (Bottoms 1995) or penal populism (Roberts et al. 2002) in Anglo-Saxon countries. Since the $1980 \mathrm{~s}$, these countries would have experienced the development of a culture of control (Garland 2001). One of the characteristics of that culture it the growth of tough on crime policies that include the introduction of harsher penalties for offending, which later extended to continental Europe (Wacquant 1998), even if with important differences across countries (Snacken and Dumortier 2012). ${ }^{20}$ This increased punitiveness seems corroborated by the upward trend shown by the rates of prisoners serving sentences for drug and violent offences; but not by the decrease of the rates of prisoners serving sentences for theft (see Fig. 4).

These divergent trends could be partially explained by the fact that the effects of harsher penalties are more visible for the most serious offences - i.e., violent offences and drug trafficking - because they lead to the longest sentences. Furthermore, such effects are even more visible in Fig. 4 because the figure is based on stock data, which implies that prisoners serving long sentences - namely those imprisoned for violent offences and drug traffickingwill be counted during several consecutive years in the annual stock. On the contrary, since sentences for property offences are shorter, an increase in their average length plays a less important role in the annual evolution of the stock of prisoners sentenced for them. However, according to these theoretical explanations, we should observe a higher increase in the rate of persons imprisoned for violent offences than in the one of those imprisoned for property offences, but not a decrease of the latter as in Fig. 4. Only the replacement of short sentences

\footnotetext{
${ }^{19}$ The reader interested in such explanations can consult the essays collected by van Dijk et al. (2012) and Tonry (2014a). Solivetti (2010) has also provided a multivariate explanation that pays particular attention to the integration of foreigners in Western Europe.

${ }^{20}$ Nelken (2010: 56-70) has clearly addressed the issues at stake in the debate on punitiveness in industrialized societies, and the complexity of such a debate from a cross-national perspective.
} 
by alternatives to imprisonment could justify such evolution, but such a replacement does not fit the theoretical framework provided by the authors that place increased punitiveness as one of the characteristics of contemporary industrialized societies. Moreover, as community sanctions and measures seem to be used as supplementary sanctions and not as alternatives to imprisonment -i.e., they are widening the net of the criminal justice systems (Cohen 1979) - their rise in Western Europe since the 1990s does not seem to have had a major impact on the evolution of prison populations Aebi et al. (2015, forthcoming).

All in all, while increased punitiveness is undoubtedly one of the causes of the rise in prison populations across Europe -as has been shown by the detailed analyses of Cavadino and Dignan (2006a)-, the changes in the composition of such populations require additional explanations. In that context, Garland's (2013) suggestion of taking crime trends into consideration seems particularly appropriate. Hence, Fig. 4 and Table 1 show that the composition of prison populations is changing because, since the mid-1990s, the rate of inmates serving sentences for property offences has been decreasing while the rates of those serving sentences for drug and violent offences have been increasing. Figure 5 shows that such trends are mirrored to a large extent by the trends observed in police and conviction statistics. The drop in property offences shown by these statistics is reflected in the fact that, as time goes by, less persons stay in prison for theft. The same is true for the increase in non-lethal violent offences registered by police and conviction statistics until the mid-2000s, which is also mirrored by a rise in the rate of inmates serving sentences for assault and rape.

Hence, the results presented in this article do not support the hypothesis of independence between crime and imprisonment. We have observed a correlation between them, and there is no plausible reason to believe that it is merely due to chance. Indeed, the correspondence between crime and imprisonment according to several types of offences, which followed different trends, suggests that there is a causal relationship. When we place these results in the framework of the model of circular causality presented in the introduction, it seems reasonable to conclude that crime came first and was followed by punishment in the form of imprisonment, but the latter did not have an impact on future crime. For example, as property offences decreased, the rate of sentenced prisoners serving sentences for such offences decreased too, and the opposite happened with non-lethal violent offences. However, the increase in the rate of persons held in custody for the latter - and the general increase in the length of detentiondid not have any noticeable deterrent effect on the rate of non-lethal violent crime.

\section{Implications for the Study of the So-called Crime Drop}

During the last two decades, criminologists have been trying to explain the decline in property and violent crime experienced in the United States since the early $1990 \mathrm{~s}^{21}$ Since the second half of the 2000s, some authors have suggested that this so-called crime drop could also be taking place in other industrialized countries, ${ }^{22}$ and references to it can be found in articles published in the first half of the 2010s. ${ }^{23}$ In the United States, trends in homicide are frequently used as an indicator of the general trends in crime, because most offences follow a similar trend as the one shown by homicide. Thus, according to the National Crime Victimization

\footnotetext{
${ }^{21}$ For a review of the main explanations proposed by researchers, see Blumstein and Wallman (2006) and Zimring (2007).

${ }^{22}$ See van Dijk (2006, 2008), van Dijk et al. (2007), Rosenfeld and Messner (2009) and Tonry (2010).

${ }^{23}$ See, for example, Farrell et al. (2011), Knepper (2012), and most of the essays collected by Van Dijk et al. (2012) and Tonry (2014a).
} 
Survey (NCVS) and the Uniform Crime Reporting Program (UCR), both property and violent offences, including homicide, have been decreasing since the early 1990s and during the 2000s (Blumstein and Wallman 2006; Truman and Planty 2012; Zimring 2007). On the contrary, as can be seen in Fig. 5, a particularity of Western Europe is that different types of crime follow dissimilar evolutions. Not only is there a difference between property and violent offences, but there are also nuances among the latter. While non-lethal violence increased until the mid 2000s, homicide was decreasing. ${ }^{24}$

In that perspective, one cannot discard the possibility that the increase in non-lethal violent offences in the 1990s and early 2000s could correspond to an artificial upward trend triggered by a growing sensitivity to violence in Western European societies, which led to changes in their criminal laws and in police recording and reporting practices (Tonry 2014b). Nevertheless, the findings of this article suggest that such increase cannot be seen only as an artefact. Indeed, serious non-lethal violent offences — serious enough to lead a person to prison - did increase in Western Europe during that period, although not in the proportion shown by police statistics. In particular, not only the percentage of prisoners serving sentences for violent offences increased (Aebi and Delgrande 2012) but, as we have seen in Fig. 4, their rate per 100,000 population also followed an upward trend in the 1990s and early 2000s. Furthermore, since the mid-2000s, the stabilization of the prison population rates coincides with the stabilization of the rates of non-lethal violent offences recorded by the police and also of the rates of offenders convicted and prisoners serving sentences for such offences. These trends are compatible with the hypothesis that crime rates in industrialized countries follow similar trends but with time lags between them, as has been the case with homicide throughout history (Eisner 2014).

Previous research has suggested that the divergences between trends in lethal and in nonlethal violence in the last decades in Western Europe could be the result of a combination of factors including (a) the growing sensitivity to violence mentioned above, (b) an increase in the reporting and recording rates of domestic violence, (c) the absence of major social conflicts, (d) the quality of health services, and (e) the relatively low rate of household gun ownership (Aebi and Linde 2010, 2012a, with references). Thus, the divergence would be partially artificial and partially factual. In particular, the low availability of guns and the improvements in the health care system imply that persons that could have been victims of homicide have become victims of assault. ${ }^{25}$

\footnotetext{
${ }^{24}$ Only England and Wales seems to be experiencing a general crime drop since the 1990s (Britton et al. 2012).

25 The evolution of offences involving the use of guns deserves particular attention. As mentioned before, Tonry (1999) considers that the main difference in crime between Europe and the United States is that the US rates of homicides, robberies, and assaults involving guns are substantially higher than in Europe. In this perspective, serious violent crime involving weapons has decreased by $26 \%$ in the United States from 2002 to 2011 (Truman and Planty 2012: 2). In Europe, in 2002/3, the police forces of England and Wales recorded 10,248 offences involving firearms; while in 2012/13 that number decreased to 5094 (Office for National Statistics 2013). In France, police statistics show that robberies with a firearm increased from 6500 in 1987 to 11,000 in 1993, and decreased after that until reaching in 2005 a lower level than in 1987; a similar trend was observed in prosecution statistics as the number of persons prosecuted for armed robberies decreased from 4200 in 1994 to 2500 in 2005 (Kensey 2007: 104). In our opinion, this decrease in the use of firearms could be one of the explanations of the contradiction between the decreasing homicide rates and the increasing rates of non-lethal violent offences in France. Indeed, the presence of a gun has a clear influence on the fatal outcome of cases of assault and domestic violence (Cook and Moore 1999: 281, with references). As a consequence, the decrease in lethal violence could be due to the decrease in the use of firearms. Indeed, as France shows in this respect the same general trends as Western Europe, the authors of this study are currently extending this kind of analysis to the rest of Europe.
} 
Finally, one must take into consideration that, as violent offences are uncommon, their influence on the trend of the total volume of crime is very limited. For example, in 2006, in the 42 countries included in the 4th edition of the European Sourcebook of Crime and Criminal Justice Statistics (Aebi et al. 2010: 37ss), the police registered a median number of 4113 offences per 100,000 population; but the median number for homicide including attempts was 3.6, for rape it was 6 , for robbery it was 55 , and for assault it was 105 . Thus, homicide, assault, rape, and robbery represented less than $5 \%$ of the total volume of police recorded crime in Europe. In contrast, during the same year, the police registered a median number of 1697 theft offences —including burglary, motor vehicle theft, and other types of theft- per 100,000 population. This means that the total volume of crime is mainly affected by the evolution of property offences, which in 2006 represented more than $40 \%$ of it. Taking into account that police statistics, conviction statistics and victimization surveys unanimously indicate a decrease in property offences in Europe since the early 1990s, it is appropriate to talk about a "decline of total volume crime" (Van Dijk et al. 2012).

In sum, the evolution of violent offences can seldom have an impact on the evolution of the total volume of crime. On the contrary, when they are serious enough to lead the offenders to prison, they can have an impact on the evolution of the prison population rate.

\section{Implications for Criminological Theories}

The findings of this article could have implications for theoretical approaches on the causes of crime. For example, in the 1970s, the overrepresentation of property offences and offenders in official statistics was often invoked by Marxist approaches to support the hypothesis of crime as a by-product of capitalist societies. According to Taylor, Walton \& Young (1975/2012: 33) an examination of official statistics on crime and its control "reveals the highly patterned, and indeed the class nature, of society and its law enforcement (and something of the patterned nature of the crimes committed)". These authors point out, for example, that $96 \%$ of crimes reported to the police in Britain were offences against property and quote Clark (1970) to assert that, in the United States, approximately seven-eighths of the reported FBI Index crimes were crimes against property, and they conclude that:

"the important feature of the official statistics is that they demonstrate what should be obvious: namely, in an inequitable society, crime is about property (and that even the various 'offences against the person' are often committed in the pursuit of property). [...] Simply put, a society which is predicated on the unequal right to the accumulation of property gives rise to the legal and illegal desire to accumulate property as rapidly as possible" (Taylor, Walton \& Young, 1975/2012: 34).

As we have seen, property offences continue to represent an important part of the crimes recorded by Western European police forces but, unlike in the 1970s when they corresponded to more than $90 \%$ of all recorded offences, their proportion fell to roughly $40 \%$ in the mid2000s. In the same perspective, according to the 2011 SPACE report, in Western Europe the number of prisoners sentenced for theft offences in 2011 represented less than $10 \%$ of the total (Aebi and Delgrande 2012). In this context, one must take into account that the development of Internet and social networking services led to new forms of property offences (e.g., illegal download of intellectual property such as songs, movies or books, credit card fraud, or ebanking fraud), which are probably not included under the category of theft. However, even if all the offences included under the general heading of others in the SPACE report were 
property offences, their total proportion would still be less than $50 \%$. This inversion of the proportion of property and violent offenders held in prisons has been observed in France by Kensey (2007) and Tournier (2011). According to the latter, in 1971, $50 \%$ of the persons held in French penal institutions were serving a sentence for common theft and $20 \%$ for violent offences (homicide, assault, and sexual aggression); while, in 2011, $7 \%$ were serving a sentence for common theft and $47 \%$ for violent offences. This means that theoretical approaches based on the axiom that "crime is about property" have currently much less empirical support than in the 1970s. At the same time, the global financial crisis that started in 2008 suggests that there is still a lot of research to be done on the crimes of the powerful, including white-collar crime, corporate crime, and state crime.

\section{Limitations of This Research}

The first limitation of this research is that there are no available data on the number of annual entries into penal institutions (flow) by type of offence. Nevertheless, the trends in persons convicted by type of offence shown in Fig. 5 can also be seen as a proxy of that figure and, as we have already mentioned, they corroborate the trends shown by prison statistics on stock. A second limitation is that there are no data available on the average length of detention by type of offence. This limitation obliged us to assume the premise that the increase in that length was distributed homogeneously across offences (i.e., that the average length of detention has increased in the same proportion for all types of offences), although this premise is clearly a matter of debate. ${ }^{26}$ Finally, a third limitation comes from the fact that one of the risks of analyzing Western European countries in a single cluster is that the general trend may hide differences across countries.

In that context, we have mentioned that the countries that did not follow the general Western European trend were Austria, Finland, and Northern Ireland in the analysis of trends in stock in 17 countries (Fig. 1), Ireland, the Netherlands, Northern Ireland, and Scotland in the analysis of trends in flow in 14 countries (Fig. 2), and Northern Ireland in the analysis of the average length of detention in the same 14 countries (Fig. 3). The Northern Ireland exception is explained by the evolution of the internal conflict related to the constitutional status of the country ("the Troubles") and its consequences on imprisonment. Finland applied, from the mid 1960s to the mid-1990s, a series of liberal reforms that resulted in a decrease in the length of custodial sentences and an extended use of fines and suspended sentences, which led to a major decrease of its imprisonment rate (Lappi-Seppälä 2012). In the case of Austria, the exception concerns only the decrease of the stock, while in the cases of the Netherlands and Scotland the exception concerns an increase in the flow.

Thus, one can conclude that, with the noteworthy exception of Finland, trends in the use of imprisonment have been strikingly similar across Western European countries during the last three decades. Even if each country has had its own particularities in terms of criminal policies, crime patterns, or political orientation of its successive governments, the overall trends in the

\footnotetext{
${ }^{26}$ For example, the analysis of Lappi-Seppälä (2012: 213) shows that, in Finland, from 1998 to 2005, the length of uncustodial prison terms imposed by the courts for aggravated assault increased by $30 \%$, but for sexual offences the increase was $17 \%$ and for aggravated drug offences $16 \%$, while the author provides no information on the length of the sentences imposed for property offences. Even if the analysis of Lappi-Seppälä (2012) also starts from a premise (i.e., the characteristics of the offences judged by the courts have been identical during the period under study), it seems plausible to accept — at least as a working hypothesis — that trends in the average length of detention vary across offences.
} 
use of imprisonment are parallel. In the same perspective, crime trends according to police and conviction statistics from 1990 to 2011 are quite similar in the vast majority of Western European continental countries. The same is true for punitiveness, whose rise seems widespread across industrialized countries, although it is possible to identify some of its local causes and mechanisms (Cavadino and Dignan 2006a, b).

\section{Conclusion}

This article has shown that prison populations (stock of inmates) increased in Western Europe from the 1980s to 2005 and seem stable since then until the end of the series in 2011. At the same time, the annual number of entries into penal institutions (flow of entries) has decreased during most of that time. This apparent paradox is explained by the fact that the average length of detention has been increasing constantly during the whole period under study. In plain words, the number of persons sent to prison decreases, but they stay in prison for longer periods of time.

The upward trend in the average length of detention is related to the development of tough on crime policies across Western Europe and to the increase in the rate of prisoners serving sentences for drug offences and for violent offences until the mid-2000s. Hence, the trends observed in the composition of prison populations mirror to a large extent the ones observed in police and conviction statistics. This means that we can answer affirmatively to the question raised in the introduction of this article: There is a relationship between crime trends and trends in imprisonment in Western Europe. Moreover, it seems fair to assert that this correlation has a causal nature in the sense that the evolution of crime affects the evolution of imprisonment. Besides, the rise of imprisonment and punitiveness did not have any deterrent effect on the rates of non-lethal violent crime and drug offences.

The findings of this article falsify thus the hypothesis of total independence between crime rates and prison population rates (see, for example, Newburn 2007) and give support to the opposite hypothesis, which suggests that there is some relationship (Garland 2013). In particular, prison population rates are influenced by the evolution of the more serious offences. This result is not completely new because historical research covering periods of more than one century conducted in Belgium (Vanneste 2001) and Italy (Melossi 2001), have already found a link between trends in the most serious offences and trends in imprisonment.

Our findings also suggest that the deterrent effect of imprisonment has been highly overestimated by some researchers (see, for example, Levitt 2004). Finally, they imply that criminological theories that place property as the main cause of crime - like the version of critical criminology presented by Taylor, Walton and Young (1975/2012: 33) - have lost the empirical support they had in the 1970s. Currently, persons imprisoned for property offences represent a minority of the prison population of Western Europe.

\section{References}

Aebi, M. F., \& Delgrande, N. (2012). Council of Europe annual penal statistics - SPACE I: survey 2011. Strasbourg: Council of Europe.

Aebi, M. F., \& Kuhn, A. (2000). Influences on the prisoner rate: number of entries into prison, length of sentences and crime rate. European Journal on Criminal Policy and Research, 8(1), 65-75. 
Aebi, M. F., \& Linde, A. (2010). Is there a crime drop in Western Europe? European Journal on Criminal Policy and Research, 16(4), 251-277.

Aebi, M. F., \& Linde, A. (2012a). Conviction statistics as an indicator of crime trends in Europe from 1990 to 2006. European Journal on Criminal Policy and Research, 18(1), 103-144.

Aebi, M. F., \& Linde, A. (2012b). Crime trends in Western Europe according to official statistics from 1990 to 2007. In J. J. M. van Dijk, A. Tseloni, \& G. Farrell (Eds.), The international crime drop: New directions in research (pp. 37-75). New York: Palgrave Macmillan.

Aebi, M. F., \& Linde, A. (2012c). Regional variation in Europe between homicide and other forms of external death and criminal offences (1970-2008). In M. C. A. Liem \& W. A. Pridemore (Eds.), Handbook of European homicide research: patterns, explanations, and country studies (pp. 7194). New York: Springer.

Aebi, M. F., \& Linde, A. (2014). The persistence of lifestyles: rates and correlates of homicide in Western Europe from 1960 to 2010. European Journal of Criminology, 11(5), 552-577.

Aebi, M. F. et al. (2006). European Sourcebook of Crime and Criminal Justice Statistics - 2006. 3rd edition. Den Haag: Boom Juridische Uitgevers. Available online at: http:/www3.unil.ch/wpmu/europeansourcebook/ files/2012/05/European-Sourcebook 3rd-ed 2006.pdf.

Aebi, M. F. et al. (2010). European Sourcebook of Crime and Criminal Justice Statistics - 2010. 4th edition. Den Haag: Boom Juridische Uitgevers. Available online at: http://english.wodc.nl/onderzoeksdatabase/europeansourcebook-4e-editie.aspx? $\mathrm{cp}=45 \& \mathrm{cs}=6796$.

Aebi, M. F. et al. (2014). European Sourcebook of Crime and Criminal Justice Statistics - 2014. 5th edition. Helsinki: HEUNI. Available online at: http://www.heuni.fi/material/attachments/heuni/reports/ qrMWoCVTF/HEUNI_report_80_European_Sourcebook.pdf.

Blumstein, A., \&Wallman, J. (2006). The Crime $\bar{D}$ rop in America. Revised edition. Cambridge [etc.]: Cambridge University Press.

Bottoms, A. E. (1995). The philosophy and politics of punishment and sentencing. In C. Clarkson \& R. Morgan (Eds.), The politics of sentencing reform (pp. 17-49). Oxford: Clarendon.

Britton, A., Kershaw, C., Osborne, S., \& Smith, K. (2012). Underlying patterns within the England and Wales crime drop. In J. J. M. van Dijk, A. Tseloni, \& G. Farrell (Eds.), The international crime drop: New directions in research (pp. 159-181). New York: Palgrave Macmillan.

Cavadino, M., \& Dignan, J. (2006a). Penal policy and political economy. Criminology and Criminal Justice, $6(4), 435-456$.

Cavadino, M., \& Dignan, J. (2006b). Penal systems: A comparative approach. London: Sage.

Clark, R. (1970). Crime in America. New York: Simon \& Schuster.

Cohen, S. (1979). The punitive city: notes on the dispersal of social control. Crime, Law and Social Change, 3(4), 339-363.

Cook, P. J., \& Moore, M. H. (1999). Guns, Gun control, and homicide: A review of research and public policy. In M. D. Smith \& M. A. Zahn (Eds.), Homicide: A sourcebook of social research (pp. 277-296). Thousands Oaks: Sage.

CoE - Council of Europe. (1999). European sourcebook of crime and criminal justice statistics. Strasbourg: Council of Europe.

Dodge, Y. (1993). Statistique: Dictionnaire encyclopédique. Paris: Dunod.

Donohue, J. J., \& Siegelman, P. (1998). Allocating resources among prisons and social programs in the battle against crime. Journal of Legal Studies, 27(1), 1-43.

Eisner, M. (2003). Long-term historical trends in violent crime. Crime and Justice, 30, 83-142.

Eisner, M. (2014). From swords to words: does macro-level change in self-control predict long-term variation in levels of homicide? Crime and Justice, 43, 65-134.

Farrell, G., Tseloni, A., Mailley, J., \& Tilley, N. (2011). The crime drop and the security hypothesis. Journal of Research in Crime and Delinquency, 48(2), 147-175.

Garland, D. (2001). The culture of control: crime and social order in contemporary society. Oxford: Oxford University Press.

Garland, D. (2013). Penality and the Penal State. Criminology, 51(3), 475-517.

Gruszczyńska, B. Z., \& Heiskanen, M. (2012). Trends in police-recorded offences. European Journal on Criminal Policy and Research, 18(1), 83-102.

Harrendorf, S., Heiskanen M., Malby, S. (2010). International Statistics on Crime and Justice. Helsinki / Vienna: European Institute for Crime Prevention and Control (HEUNI) / United Nations Office on Drugs and Crime (UNODC).

Kensey, A. (2007). Prison et récidive. Des peines plus longues : la société est-elle vraiment mieux protégée? Paris: Armand Colin.

Killias M. et al. (2003). European Sourcebook of Crime and Criminal Justice Statistics 2003. Den Haag: Boom Juridische uitgevers. Available online at: http://www.minjust.nl:8080/b_organ/wodc/reports/ob212i.htm. 
Knepper, P. (2012). An international crime decline: lessons for social welfare crime policy? Social Policy and Administration, 46(4), 359-376.

Kuhn, A., Tournier, P., \& Walmsley, R. (2000). Report on prison overcrowding and prison population inflation. Strasbourg: Council of Europe.

Lappi-Seppälä, T. (2011). Explaining imprisonment in Europe. European Journal of Criminology, 8(4), 303-328.

Lappi-Seppälä, T. (2012). Criminology, crime and criminal justice in Finland. European Journal of Criminology, 9(2), 206-222.

Levitt, S. D. (1998). Juvenile crime and punishment. Journal of Political Economy, 106(6), 1156-1185.

Levitt, S. D. (2004). Understanding why crime fell in the 1990s: four factors that explain the decline and six that do not. Journal of Economic Perspectives, 18(1), 163-190.

Melossi, D. (2001). Le crime de la modernité : sanctions, crime et migration en Italie (1863-1997). Sociologie et Societes, 33(1), 85-106.

Morin, E. (1992). Method: Towards a Study of Humankind. Vol. 1: The Nature of Nature. New York: Peter Lang (First published in French in 1977: La méthode. Tome 1: La nature de la nature. Paris: Seuil

Nelken, D. (2009). Comparative criminal justice beyond ethnocentrism and relativism. European Journal of Criminology, 6(4), 291-311.

Nelken, D. (2010). Comparative criminal justice. Los Angeles: Sage.

Newburn, T. (2007). Criminology. Cullompton: Willan.

Office for National Statistics. (2013). Crime in England and Wales, year ending March 2013. London: Office for National Statistics.

Ouimet, M. (2012). L'argent et le sang: comment la pauvreté et les homicides expliquent les variations du taux d'incarcération dans le monde en 2010. Revue Internationale de Criminologie et de Police Technique et Scientifique, 65(2), 239-263.

Pinker, S. (2011). The better angels of our nature: why violence has declined. New York: Penguin.

Roberts, J. V., Stalans, L. J., Indermaur, D., \& Hough, M. (2002). Penal populism and public opinion: lessons from five countries. Oxford: Oxford University Press.

Rosenfeld, R., \& Messner, S. F. (2009). The crime drop in comparative perspective: the impact of the economy and imprisonment on American and European burglary rates. The British Journal of Sociology, 60(3), 445-471.

Snacken, S., \& Dumortier, E. (Eds.). (2012). Resisting punitiveness in Europe?: Welfare, human rights and democracy. Abingdon: Routledge.

Solivetti, L. M. (2010). Immigration, social integration and crime. A cross-national approach. Oxon: Routledge.

Spelman, W. (2000). What recent studies Do (and don't) tell us about imprisonment and crime. Crime and Justice, 27, 419-494.

Taagepera, R. (2008). Making social sciences more scientific: the need for predictive models. Oxford: Oxford University Press.

Taylor, I., Walton, P., \& Young, J. (2012). Critical criminology in Britain: review and prospects. In I. Taylor, P. Walton, \& J. Young (Eds.), Critical criminology. Oxon: Routledge. First published in 1975.

Tonry, M. (1999). Why are U.S. Incarceration rates so high? Crime \& Delinquency, 45(4), 419-437.

Tonry, M. (2010). Why are crime rates falling (or are they)? Criminology in Europe: Newsletter of the European Society of Criminology, 9(1), 3.

Tonry, M. (Ed.) (2014a). Why Crime Rates Fall, and Why They Don't. Crime and Justice, 43. Chicago: The University of Chicago Press.

Tonry, M. (2014b). Why crime rates are falling throughout the western world. Crime and Justice, 43, 1-63.

Tournier, P. V. (2004). Systems of Conditional Release (Parole) in the Member States of the Council of Europe. Champ pénal/Penal field [online], I/2004. Available online at (27-11-2012): http://champpenal.revues.org/ 378

Tournier, P. V. (2011). Arithmétique pénitentiaire. Arpenter le Champ pénal, 9(Supplément d'été № 4), 2-8.

Truman, J. L., \& Planty, M. (2012). Criminal victimization, 2011. Washington: U.S. Department of Justice, Office of Justice Programs, Bureau of Justice Statistics.

Van Dijk, J. J. M. (2006). What Goes up, comes down: Explaining the falling crime rates. Criminology in Europe: Newsletter of the European Society of Criminology, 5(3), 3, 17-18.

Van Dijk, J. J. M. (2008). The world of crime: breaking the silence on problems of security, justice, and development across the world. Los Angeles: Sage.

Van Dijk, J. J. M., Tseloni, A., \& Farrell, G. (Eds.). (2012). The international crime drop: New directions in research (pp. 159-181). New York: Palgrave Macmillan.

Van Dijk, J. J. M., van Kesteren, J., \& Smit, P. (2007). Criminal victimization in international perspective: Key findings from the 2004-2005 ICVS and EU ICS. Den Haag: Boom Juridische Uitgevers.

WHO - World Health Organization. (2014). Health for all database (HfA). Technical notes. [Geneva: World Health Organization]. Available online at: http://data.euro.who.int/hfadb/help/Technical\%20notes.htm. Accessed 18 Feb 2015. 
Vanneste, C. (2001). Les chiffres des prisons: Des logiques économiques à leur traduction pénale. Paris: L'Harmattan.

Von Hofer, H., Lappi-Seppälä, T., \& Westfelt, L. (2012). Nordic criminal statistics 1950-2010. Stockholm: Kriminologiska institutionen, Stockholms universitet.

Wacquant, L. (1998). La tentation pénale en Europe. Actes de la Recherche en Sciences Sociales, 124, 3-6. Zimring, F. E. (2007). The great American crime decline. Oxford: Oxford University Press.

Zimring, F. E., \& Hawkins, G. (1997). Crime is not the problem: lethal violence in America. New York: Oxford University Press. 